\title{
Earlier-Bolting Spinach Cultivars Respond to a Wider Spectrum of Night-Break Light for Bolting than Later-Bolting Cultivars
}

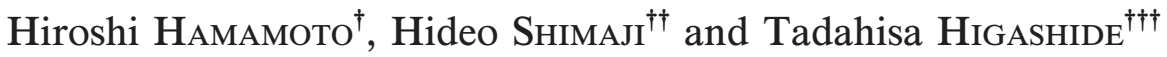 \\ (National Research Institute of Vegetables, Ornamental Plants and Tea,
Taketoyo, Aichi, 470-2351 Japan
}

\begin{abstract}
We investigated varietal differences in reproductive responses of spinach (Spinacia oleracea L.), a long-day plant, to 2-h night-break treatments with light of various wavelengths provided by light-emitting diodes of various colors. In the first experiment, medium-early-bolting cv. 'Alrite' and late-bolting cv. 'Summer Focus' were treated with blue, green, yellow, red, far-red, or no light. Both cultivars showed high night-break sensitivity to red, yellow, and green light and low sensitivity to blue light for bolting, but 'Alrite' was much more sensitive to far-red light than 'Summer Focus.' In the second experiment, we added medium-early-bolting cv. 'Atlanta' and late-bolting cv. 'Active.' These cultivars were night-broken by red, far-red or no light. Bolting of earlier-bolting cultivars 'Alrite' and 'Atlanta' was accelerated more by far-red night-break treatment than that of laterbolting cultivars 'Active' and 'Summer Focus.' These results suggest that earlier-bolting cultivars of spinach have a wider range of effective night-break wavelengths for bolting than later-bolting cultivars.
\end{abstract}

Key words: Light wavelength, Precocity, Reproductive response, Spinacia oleracea, Varietal difference.

\section{Introduction}

Varietal differences have been reported in the bolting of spinach, a long-day plant, under night-break treatment with incandescent lamps (Furuya et al., 1997) and under day-elongation treatment with mercury vapor lamps (Takao, 1998). Those studies used only one type of light source each. Little attention has been given to the relationship between varietal differences in response and spectra of light. We reported that the reproductive response of spinach to night-break treatment with far-red light probably differs by cultivar (Hamamoto et al., 2003). However, there are few studies of varietal differences in the

\footnotetext{
${ }^{\dagger}$ Present address : National Agricultural Research Center for Western Region, Ayabe, Kyoto, 623-0035 Japan

${ }^{\dagger \dagger}$ Present address : National Institute of Floricultural Science, Tsukuba, Ibaraki, 305-8519 Japan

${ }^{\dagger \dagger \dagger}$ Present address : National Agricultural Research Center for Western Region, Zentsuji, Kagawa, 765-8508 Japan

Received on November 20, 2003.

Accepted on May 19, 2004.
}

response of spinach to the wavelength of night-break light.

Accordingly, this study was designed to investigate varietal differences in reproductive responses of spinach to night-break treatment with light of various wavelengths. We used light-emitting diodes (LEDs) as the light source. LEDs have higher efficiencies of conversion of electricity to light and last longer than incandescent lamps, which are commonly used for both night-break and day-elongation treatments. LEDs have been investigated as supplemental light sources for night-break treatments (Kawai et al., 1996; Watanabe et al., 1996). Their narrow-band spectral emissions (Schuerger et al., 1997) make them useful for studies of the effects of light wavelengths on plant physiology and growth.

\section{Materials and Methods}

\subsection{Experiment 1}

We used two cultivars of spinach (Spinacia oleracea L. cvv. 'Alrite' and 'Summer Focus'; Takii Seed Co., Ltd., Kyoto, Japan). 'Alrite' is a mediumearly-bolting cultivar and 'Summer Focus' is a latebolting cultivar (Kagawa, 1997). The plants were 
planted in 90-mL plastic pots filled with fertilized soil

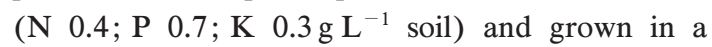
greenhouse. The greenhouse was heated when the temperature fell below $13^{\circ} \mathrm{C}$ and ventilated when the temperature rose above $30^{\circ} \mathrm{C}$.

We used five night-break treatments with a different color each and a control treatment without nightbreak. Light was provided by 5 LED panels with peak photon emissions of $475 \mathrm{~nm}$ (blue), $530 \mathrm{~nm}$ (green), $576 \mathrm{~nm}$ (yellow), $655 \mathrm{~nm}$ (red), and $745 \mathrm{~nm}$ (far-red). Their spectral distributions are described by Hamamoto et al. (2003). Each LED panel measured $350 \mathrm{~mm} \times 400 \mathrm{~mm}$ and consisted of 800 individual LEDs. Each panel was mounted on the ceiling of a steel frame measuring $600 \mathrm{~mm}$ wide $\times 400 \mathrm{~mm}$ long $\times 730 \mathrm{~mm}$ high. Before the experiment, the photon flux density from each panel was measured with a spectroradiometer (LI-1800, Li-Cor, Inc.) and set to give 8 to $10 \mu \mathrm{mol} \mathrm{m}^{-2} \mathrm{~s}^{-1}$ of photon flux at floor level below the center of each.

Five plants of each cultivar were used per treatment. The plants were grown in the steel frames, which were covered on their sides and back with shadecloth from 1700 to $0900 \mathrm{~h}$ daily so that the plants could not be illuminated by LEDs of other colors. The LEDs irradiated the plants from 2300 to $0100 \mathrm{~h}$ daily as night-break, beginning 26 January 2001, when the plants had reached the 2-leaf stage.

\subsection{Experiment 2}

We used two cultivars of medium-early-bolting spinach, 'Alrite' and 'Atlanta'* (Kagawa, 1997), and two cultivars of late-bolting spinach, 'Active'* (Kagawa, 1997) and 'Summer Focus' (*Sakata Seed Co., Yokohama, Japan).

The plants were planted in $780-\mathrm{mL}$ plastic pots filled with fertilized soil (fertilizer as in experiment 1). Four plants of each cultivar with two leaves were placed in frames with red, far-red, or no LEDs. Night-break treatment as in experiment 1 was carried out from 21 March 2000.

\section{Results and Discussion}

Figure 1 shows the results of experiment 1 . In the green, yellow, red, and far-red treatments, average stem lengths of spinach were more than $5 \mathrm{~cm}$ on 16 February (day 21 of treatment), when average stem lengths in the control and blue-light treatments were 0.2 and $0.3 \mathrm{~cm}$. On 23 February (day 28), stems (= flower stalks) were 23.7 to $25.6 \mathrm{~cm}$ in the green- light treatment, 19.4 to $30.5 \mathrm{~cm}$ in the yellow-light treatment, 18.1 to $26.4 \mathrm{~cm}$ in the red-light treatment, and 18.2 to $21.2 \mathrm{~cm}$ in the far-red-light treatment. Average stem lengths in the control and blue-light treatments were 0.2 and $0.4 \mathrm{~cm}$ on that day (Fig. 1a).

'Summer Focus' plants bolted later than did 'Alrite.' Average stem lengths in green-, yellow-, and red-light treatments showed flower stalks longer than $7 \mathrm{~cm}$ on 23 February (day 28 of treatment). On 3 March (day 36), stems measured 18.8 to $27.5 \mathrm{~cm}$ in the green-light treatment, 19.4 to $27.9 \mathrm{~cm}$ in the yellow, and 20.0 to $24.2 \mathrm{~cm}$ in the red, but those in the far-red- and blue-light treatments were $<4 \mathrm{~cm}$ and $<1 \mathrm{~cm}$, respectively. Control 'Summer Focus' plants had not bolted, and their average stem length was $0.3 \mathrm{~cm}$ on that day (Fig. 1b).

Figure 2 shows the results of experiment 2. 'Alrite' stem elongation was fastest in the red-light treatment and slowest in the control treatment (Fig. 2a). Average stem lengths in the red- and far-red-
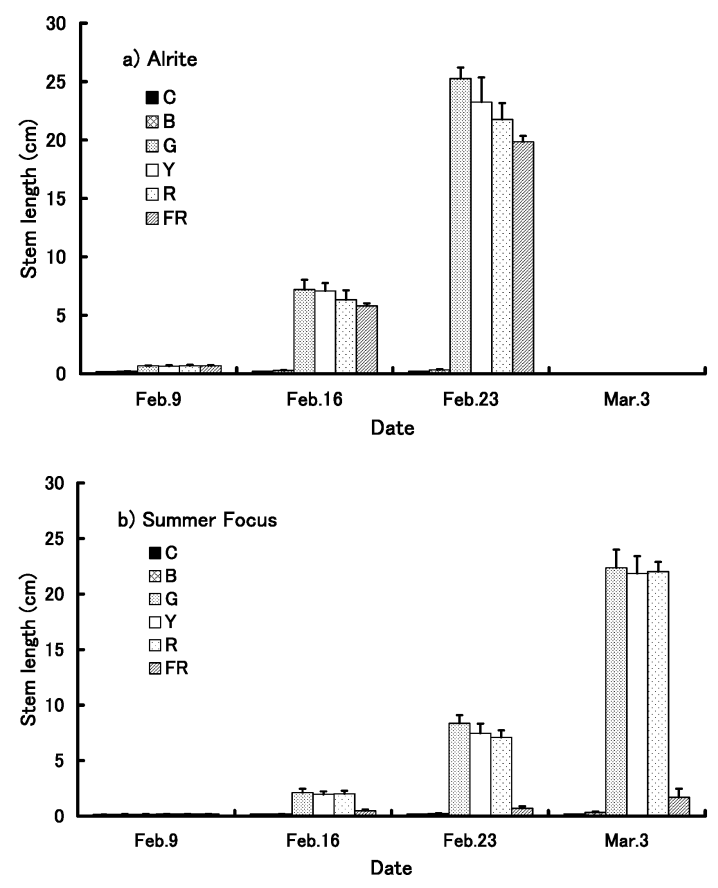

Fig. 1. Stem length in 'Alrite' (a) and 'Summer Focus' (b) spinach. Night-break treatments: C, control treatment without night-break; B, blue light; G, green light; Y, yellow light; R, red light; FR, far-red light. Vertical bars indicate standard error $(n=5)$. 

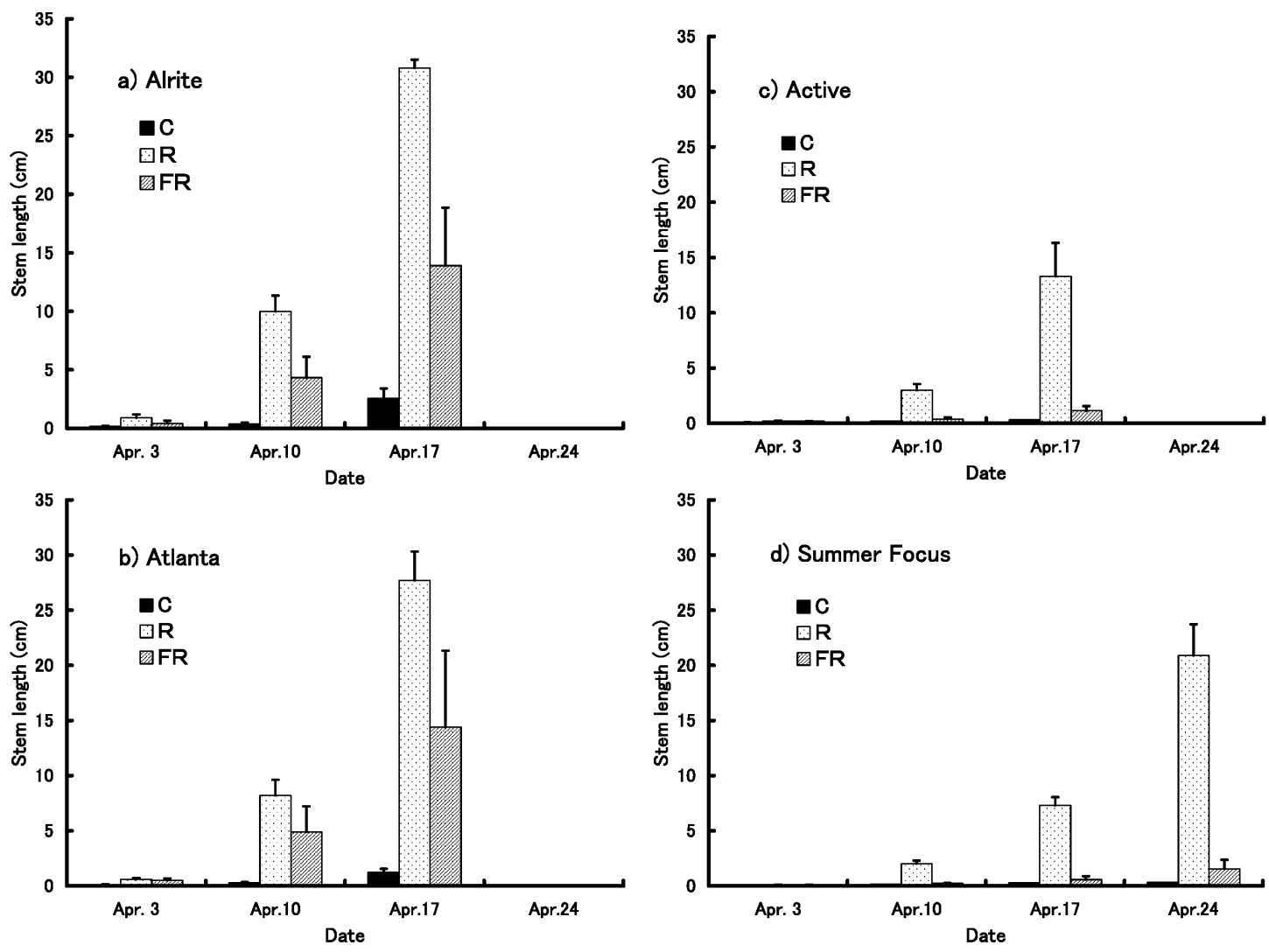

Fig. 2. Stem length in 'Alrite' (a), 'Atlanta' (b), 'Active' (c), and 'Summer Focus' (d) spinach. Nightbreak treatments: C, control treatment without night-break; R, red light; FR, far-red light. Vertical bars indicate standard error $(n=4)$.

light treatments were more than 30 and $13 \mathrm{~cm}$, respectively, while average stem length in the control was less than $3 \mathrm{~cm}$ on 17 April (day 26 of treatment).

Stem elongation in 'Atlanta' was fastest in the red-light treatment and slowest in the control treatment, as in 'Alrite' (Fig. 2b). On 17 April (day 26 of treatment), average stem lengths were about 28, 15, and $1 \mathrm{~cm}$ in the red-light, far-red-light, and control treatments.

'Active' stem elongation was much faster in the red-light treatment than in the other treatments (Fig. 2c). Stem lengths of the red-light-treated plants were all more than $8 \mathrm{~cm}$ on 17 April (day 26 of treatment). Stem lengths of the plants in the far-red light treatment measured 0.3 to $2.3 \mathrm{~cm}$ on that day. Control plants had not bolted; their average stem length was $0.3 \mathrm{~cm}$ on that day.

Stems of 'Summer Focus' elongated fastest in the red-light treatment (Fig. 2d). The average stem length was $>20 \mathrm{~cm}$ on 24 April (day 33), when average stem lengths in the far-red-light and control treatments were $1.5 \mathrm{~cm}$ and $0.3 \mathrm{~cm}$, respectively.

Both earlier-bolting 'Alrite' and later-bolting 'Summer Focus' showed high sensitivity to red, yellow, and green light and low sensitivity to blue light in experiment 1 . The earlier-bolting cultivar 'Alrite' or 'Atlanta' responded to far-red night-break light more strongly than did the later-bolting cultivar 'Active' or 'Summer Focus' in either experiment. Stolwijk (1952) reported that the bolting of 'Nobel' spinach, a late-bolting cultivar by Kagawa's classification (Kagawa, 1997), was not accelerated by dayelongation treatment with far-red light but was accelerated by green, yellow, and red light. Those results suggest that earlier-bolting cultivars of spinach, a long-day plant, have a wider range of effective 
night-break wavelengths for bolting than laterbolting cultivars. It is possible that late-bolting spinach cultivars have few photoreceptors that work for bolting in response to far-red light at night.

In contrast with spinach, a previous study using cosmos, a short-day plant, found that an earlierflowering cultivar, 'Versailles,' had a narrower effective spectrum than a later-flowering cultivar, 'Radians' (Hamamoto et al., 2002). The results of our study and the reports described above indicate that the precocity of cultivars of both long-day and short-day plants can be affected by the bandwidth of the wavelengths critical for flower development in those plants. Cultivars that respond to a wider range of light spectrum may perceive daylight earlier and evening later because they can use more photons for their perception of daytime than cultivars that respond to a narrower spectrum range. Disappointingly, there are very few studies of the relationship between varietal precocity and critical spectra in long-day or short-day plants. We have found that the former may be related to the latter in spinach, but further studies are needed for a complete understanding of this relationship.

\section{Acknowledgements}

We would like to thank Mr. H. Iwakiri and Mrs. M. Yokoo for their technical assistance.

\section{References}

Furuya, S., Yasuba, K. and Hamamoto, H., 1997: Effects of long-day treatment by light break on flower stalk development of spinach cultivars. $J$. Jpn. Soc. Hort. Sci., 66 (Suppl. 2), 446-447 (in Japanese).
Hamamoto, H., Shimaji, H., Higashide, T., Nishimura, M. and Shimazu, T., 2002: Bolting and flowering in some spinach and cosmos cultivars under night-break treatments with some wavelength lights. J. Jpn. Soc. Hort. Sci., 71 (Suppl. 1), 120 (in Japanese).

Hamamoto, H., Shimaji, H. and Higashide, T., 2003: Budding and bolting responses of horticultural plants to night-break treatments with LEDs of various colors. J. Agric. Meteorol., 59, 103-110.

Kagawa, A., 1997: Physiology in cultivation of high quality spinach. Ishizue, Tokyo, pp. 7-15 (in Japanese).

Kawai, S., Watanabe, H., Yoshino, T., Tanaka, F. and Suzuki, M., 1996: Light emitting diodes as the light source for plant growth regulations. 4. Flowering regulation of chrysanthemum by irradiation of LEDs in summer. J. Jpn. Soc. Hort. Sci., 65 (Suppl. 1), 454-455 (in Japanese).

Schuerger, A. C., Brown, C. S. and Stryjewski, E. C., 1997: Anatomical features of pepper plants (Capsicum annuиm L.) grown under red light-emitting diodes supplemented with blue or far-red light. Ann. Bot., 79, 273-282.

Stolwijk, J. A. J., 1952: Photoperiodic and formative effects of various wavelength regions in Cosmos bipinnatus, Spinacia oleracea, Sinapis alba and Pisum sativum. I. Proc. Kon. Ned. Akad., C55, 489-497.

Takao, Y., 1998: Effects of night lighting and critical illuminance on the growth and bolting of spinach cultivars. J. Jpn. Soc. Hort. Sci., 67, 778-784 (in Japanese with English summary).

Watanabe, H., Kawai, S., Yoshino, T., Tanaka, F. and Suzuki, M., 1996: Light emitting diodes as the light source for plant growth regulations. 3. Flowering regulation of chrysanthemum by irradiation of LEDs in winter. J. Jpn. Soc. Hort. Sci., 65 (Suppl. 1), 452-453 (in Japanese). 


\section{抽だいの早いホウレンソウ品種は遅い品種よりも 暗期中断に反応する光波長域が広い}

浜本 浩 $^{\dagger} \cdot$ 島地英夫 ${ }^{\dagger \dagger} \cdot$ 東出忠桐 ${ }^{\dagger \dagger}$

(野菜・茶業試験場)

要 約

数色の発光ダイオード (LED) で 2 時間暗期中断する 条件下で，暗期中断の光波長がホウレンソウの抽だいへ 及ぼす影響の品種間差を調査した。まず，抽だい性が中 程度の ‘Alrite’ と晚抽性の ‘Summer Focus’ に青, 緑, 黄, 赤, 遠赤色光で処理したが, 両品種とも赤, 黄, 緑色光で敏感に抽だい反応し, 青色光での反応が鈍いこ とが示された。しかし遠赤色光では差異が生じ, 'Alrite’ではよく反応したのに対し, 'Summer Focus' では反応が鈍かった。次に，上記 2 品種に中抽だい性の 'Atlanta' と晚抽性の 'Active' を加えて赤と遠赤色光
で処理を行ったが, 抽だいの早い品種 'Alrite’ と'Atlanta' が遠赤色光への抽だい反応が敏感であったのに 対し, 抽だいの遅い品種 'Active’ と 'Summer Focus' では鈍い反応しか得られなかった。

キーワード: Spinacia oleracea, 生殖生長反応, 抽だい 性, 光波長, 品種間差

†現在 : 近畿中国四国農業研究センター

${ }^{\dagger \dagger}$ 現在 : 花き研究所

${ }^{\dagger \dagger}$ 現在 : 近畿中国四国農業研究センター 